\title{
Psychological Empowerment and Organizational Innovation: Mediating Role of Job Satisfaction and Organizational Commitment
}

\author{
Amin Nikpour* \\ Department of Management, Kerman Branch, Islamic Azad University, Kerman, Iran.
}

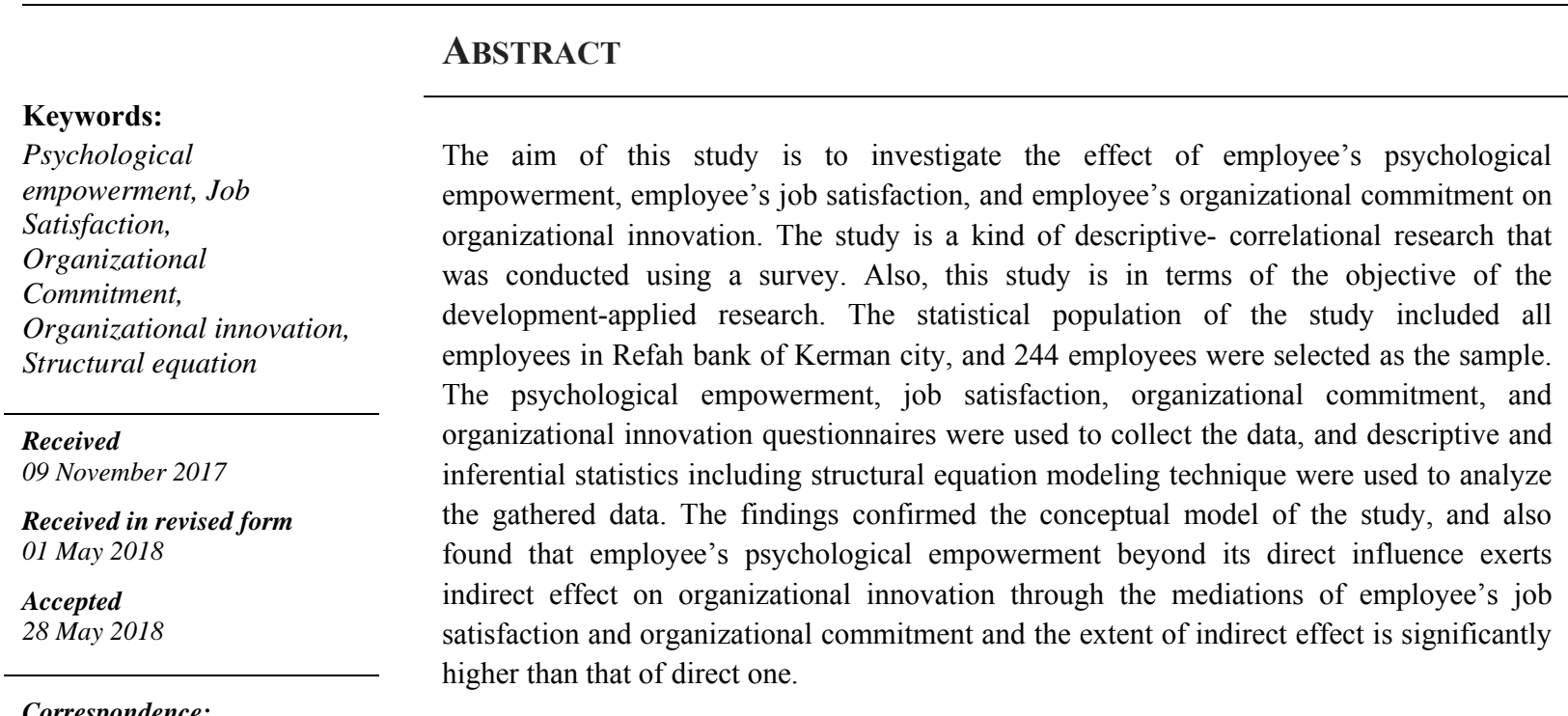

nikpour2003@yahoo.com

(C)AIMI Journals

Today's world is often described as a place that is constantly changing, markets are not stable, and political and legal contexts are shifting more than before. Furthermore, technological changes have increased the speed of communication which requires organizations to examine and respond to the changes. Meanwhile, small and medium-sized enterprises are heavily affected by environmental changes due to limited resources and capital. Therefore, organizations must seek competitive advantage to remain in this dynamic and changing environment (Rahimnia \& Sajjad, 2015). In addition, organizational innovation is the key to 
survival in a competitive environment and the most important source of competitive advantage (Bas, Mothe, \& Nguyen-Thi, 2015; Hill \& Jones, 2012;). This is because it can lead to the production of new products and services that better meet the needs of customers, and can improve the quality of existing products or can reduce production costs (Hill \& Jones, 2012; Yesil, Koska, \& Buyukbese, 2013). Therefore, it is hard to speak about growth and competitiveness if there is no innovation in organization (Yesil, Koska, \& Buyukbese, 2013). And an organization's ability to innovate is recognized as one of the determinant factors to survive and succeed (Quinn, 2000).

On the other hand, there are various approaches to achieve innovation in organizations. One of these practical approaches is the human capital approach (Alshekaili \& Boerhannoeddin, 2011). In fact, the human capital of each company is one of the important factors influencing the innovation of companies (Pizarro, Real, \& Rosa, 2009). The tools that can help improve the quality of human capital with the help of company managers are empowerment, enhancing job satisfaction and organizational commitment of this human capital. As the theoretical evidence suggests, employees are empowered, more satisfied, more committed, and more innovative (Lau, 2011).

Although the word "empowerment" may have been used in similar forms or terms, the scientific term can be ascribed to "Mary Parker Follett" (Herbert, 2009). Empowerment means granting power, participation in decision making, receiving appropriate information, autonomy, creativity and innovation in work, having knowledge and the necessary skills and accepting responsibility (Petter, Byrnes, Choi, Fegan, \& Miller, 2002). Empowerment is the personal belief by which people can enhance the skills and knowledge and act according to it (Bogler \& Somech, 2004). Employee empowerment is a process of giving authority to the employees to make important decisions on their own about their day to day activities (Jafari, Moradi, \& Ahanchi, 2013). Psychological empowerment is an internal motivating factor that reflects the active role of employees in the organization (Thomas \& Velthouse, 1990). Psychological empowerment includes competence, self-determination, impact, trust, and meaning (Whetten \& Cameron, 2015).

Job satisfaction is a pleasurable emotional state resulting from the appraisal of one's job (Brief \& Weiss, 2002). Lund (2003) defined job satisfaction as the amount of observed communication between what a person demands from his job with what has given to him by the job and the organization. Gunlu, Aksarayli and Sahin Perçin (2010) explained job satisfaction as a kind of reaction to a particular job or an issue is related to a job. Acoording to Antoncic and Antoncic (2011), job satisfaction refers to the employees' satisfaction with their job and the amount of interest in job-related activities. Low job satisfaction, leads to negative implications such as isolated behavior, increased cost, reduced profits and customer dissatisfaction (Abdulla, Djebarni \& Mellahi, 2011). Job satisfaction includes satisfaction of pay, coworkers, work, and supervision (Vitell \& Davis, 1990).

Organizational commitment has become one of the most fashionable variables studied in the last three or four decades. Like every other psychological construct, it is quite hard to have a universally accepted definition (Suma \& Lesha, 2013). Organizational commitment is defined as the relative degree of identification with the organization and participation in it (Allen \& Meyer, 1990). As Dee, Henkin and Singleton (2006) noted organizational commitment is the 
relative strength of identification with and involvement in an organization, acceptance of organizational goals, and willingness to exert effort to remain in that organization. Cichy, Cha and Kim (2009) referred to organizational commitment as the extent to which a person internalizes values, goals, sense of loyalty and dutifulness to the workplace. Gunlu, Aksarayli and Sahin Perçin (2010) described organizational commitment as an overall reaction to the total organization. Organizational commitment includes affective commitment, continuance commitment, and normative commitment (Meyer \& Herscovitch, 2001).

The concept of innovation has changed significantly over the past four decades. In the 1950s, innovation was a discontinuous event that originated from the knowledge created by researchers and inventors, but nowadays, innovation is the result of a process that comes from a wide-ranging collaboration of many factors (Landry, Amara, \& Lamari, 2002). Organizational innovation is willingness of an organization to develop new and improved products and services and deliver them to market for getting success (Gumusuluoglu \& Ilsev, 2009). Organizational innovation can refer to either 'new-to-the-state-of-the-art' or 'new-to-the-firm' (Mol \& Birkinshaw, 2009). Innovation is to conform to an idea or behavior that is new to the organization (Tamayo-Torres, Ruiz-Moreno, \& Verdú, 2010). Organizational innovation is defined as an organizational method in a firm's business practices, workplace organization or external relations that is new to the firm and intended to improve the firm's performance (Steiber, 2012). The concept of innovation is defined as the successful implementation of useful creative ideas within the firm (Racela, 2014). Additionally, innovation can be described as a new idea, application or object that is newly accepted by an individual or another application unit (Celik, Iraz, Cakıci, \& Celik, 2014). Organizational innovation includes product innovation, market innovation, process innovation, behavior innovation, and strategic innovation (Wang \& Ahmed, 2004).

Regarding the above discussion, the purpose of this research is to investigate the effect of employee's psychological empowerment, job satisfaction, and organizational commitment on organizational innovation.

\section{Empowerment and Organizational Innovation}

Yang and Alison (2011) conducted a study that examined the interactive effects of workplace diversity and employee involvement on organizational innovation. This research demonstrated that there is a positive relationship between the level of employee involvement and the organizational innovation. Ertürk (2012) concluded that psychological empowerment of employee is strongly and positively related to innovation capability. Singh and Sarkar (2012) found that having greater control over one's non-work domain influenced psychological empowerment, which then had a positive influence on innovative behaviors. In addition, when people felt their work had meaning, they tended to be more involved in their job, which also tended to have a positive influence on innovative behavior. Berraies, Chaher and Benyahia (2014) expressed that employee empowerment has a positive effect on innovation. Celik, Iraz, Cakıci and Celik (2014) concluded that there is a meaningful relationship between employee empowerment and innovativeness. Madhavan (2014) suggested that there is positive relationship between employees empowerment and their innovation in the work. 


\section{Empowerment and Job Satisfaction}

Laschinger, Finegan, Shamian and Wilk (2004) stated that workplace empowerment has impact on job satisfaction. Hamed (2010) expressed that there is a positive association between employee empowerment and job satisfaction. Mushipe (2011) found that there is a positive relationship between employee involvement and job satisfaction. Kazlauskaite, Buciuniene and Turauskas (2012) concluded that organizational empowerment has impact on job satisfaction. Elnaga and Imran (2014) examined the relationship between employee empowerment and job satisfaction by reviewing and determining all factors which affect on this relation. They found that empowerment can lead to job satisfaction.

\section{Empowerment and Organizational Commitment}

Liu, Fellows and Chiu (2006) found that perceived empowerment does correlate with organizational commitment. Chen and Chen (2008) concluded that there is positive and significant relationship between dimensions of empowerment and organizational commitment. Ismail, Mohamed, Sulaiman, Mohamad and Yusuf (2011) noted that there is a positive relationship between empowerment and organizational commitment. Kazlauskaite, Buciuniene and Turauskas (2012) did the research titled "Organizational and psychological empowerment in the HRM-performance linkage". This research demonstrated that organizational empowerment has impact on affective commitment. Goudarzvandchegini and Kheradmand (2013) in a study entitled "the relationship between empowerment and organizational commitment" concluded that there is significant relationship between empowerment and organizational commitment.

\section{Job Satisfaction and Organizational Innovation}

In their study, Shipton, West, Parkes, Dawson and Patterson (2006) found that there is a relationship between aggregate job satisfaction and innovation. Lambert and Hogan (2010) concluded that perceptions of organizational innovation had statistically significant positive associations with job satisfaction. Tien and Chao (2012) stated that job satisfaction has impact on organizational innovation. Ghoochkanloo and Talebieshlaghi (2016) explained that employee's job satisfaction has a significant impact on the innovation of the organization.

\section{Organizational Commitment and Organizational Innovation}

Ming and Ying (2010) demonstrated that affective commitment directly and indirectly had significant and positive effects on both of technological innovation and administrative innovation; continuance commitment directly and indirectly had significant and negative effects on both of technological innovation and administrative innovation; and normative commitment directly and indirectly had a significant and positive effect on technological innovation. Lambert and Hogan (2010) concluded that perceptions of organizational had statistically significant positive associations with organizational commitment. Holliman (2012) found that there is a relationship between organizational commitment of teachers and innovation and higher levels of commitment were associated with higher levels of innovation. Rostami, Veismoradi and Akbari (2012) noted that there is significant relationship between organizational commitment and innovation. 


\section{Job Satisfaction and Organizational Commitment}

Meyer, Stanley, Herscovitch and Topolnytsky (2002) found that job satisfaction is a determinative of organizational commitment. Adekola (2012) posited that organizational commitment has a significant impact on job satisfaction. Yucel and Bektas (2012) concluded that job satisfaction positively correlated with organizational commitment. Suma and Lesha (2013) explained that dimensions of job satisfaction as work-itself, quality of supervision and pay have significant positive influence on organizational commitment of employees.

\section{Conceptual Model}

In this research, for the design of variables of psychological empowerment, job satisfaction, organizational commitment and organizational innovation, the models by Whetten and Cameron (2015), Vitell and Davis (1990), Meyer and Herscovitch (2001), Wang and Ahmed (2004) were used respectively. The reason for using these models is that these models have the most citations. Figure 1 shows the conceptual model of research:

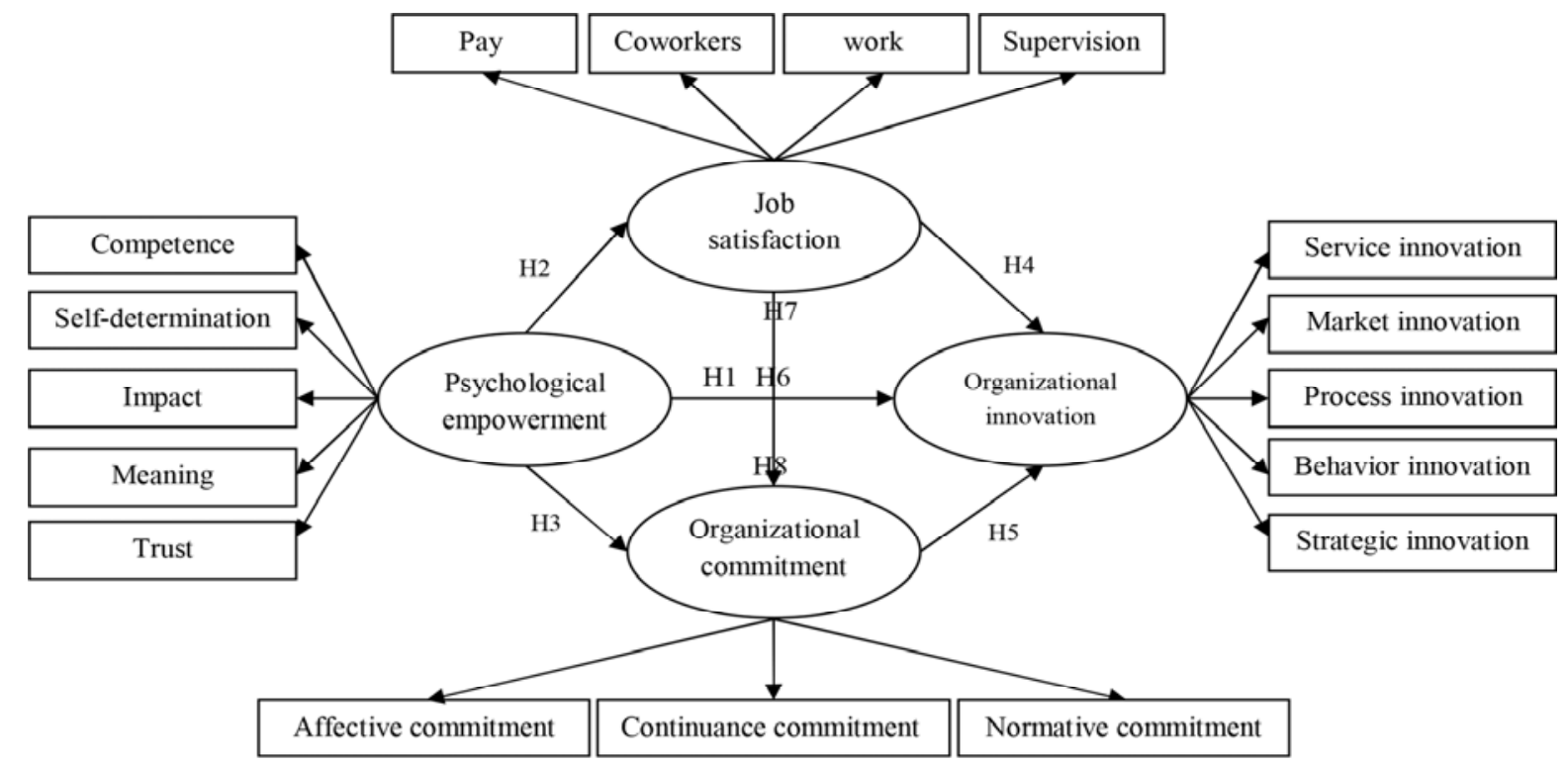

Figure 1. Conceptual model of study

\section{Hypotheses}

According to the conceptual model of study, the study hypotheses are presented as follows:

$\mathbf{H}_{1}$ : Employee's psychological empowerment has an effect on organizational innovation.

$\mathbf{H}_{2}$ : Employee's psychological empowerment has an effect on employee's job satisfaction.

$\mathbf{H}_{3}$ : Employee's psychological empowerment has an effect on employee's organizational commitment.

$\mathbf{H}_{4}$ : Employee's job satisfaction has an effect on organizational innovation.

H5: Employee's organizational commitment has an effect on organizational innovation.

H$_{6}$ : Employee's job satisfaction has an effect on Employee's organizational commitment.

$\mathbf{H}_{7}$ : Employee's job satisfaction mediates the relationship between employee's psychological empowerment and organizational innovation. 
H8: Employee's organizational commitment mediates the relationship between employee's psychological empowerment and organizational innovation.

\section{Method}

The present study is a descriptive- correlational research that was conducted using a survey. Also, this study is a development-applied research. The statistical population of the study included all employees in Refah bank of Kerman city. The number of employees during the study was 600 people, and 244 employees were selected as the sample using Cochran's formula (because it was likely that some questionnaires were not going to be returned or answered completely, 300 questionnaires were distributed among the statistical population). Four questionnaires were used to collect the data which were standard and were adjusted based on the range of 5 scales of Likert ( $1=$ strongly disagree to $5=$ strongly agree). The first questionnaire includes 15 questions and evaluates the employees' psychological empowerment through its dimensions as competence (3 questions), self-determination (3 questions), impact (3 questions), meaning (3 questions) and trust (3 questions). The second questionnaire includes 11 questions and evaluates the employees' job satisfaction through its dimensions as pay (3 questions), coworkers (2 questions), work (3 questions) and supervision (3 questions). The third questionnaire includes 24 questions and evaluates the employees' organizational commitment through its dimensions as affective commitment (8 questions), continuance commitment ( 8 questions) and normative commitment ( 8 questions). The fourth questionnaire includes 20 questions and evaluates organizational innovation through its dimensions as service innovation (4 questions), market innovation (4 questions), process innovation (4 questions), behavior innovation (4 questions), and strategic innovation (4 questions).

Regarding the validity and reliability, the psychological empowerment, job satisfaction, organizational commitment, and organizational innovation questionnaires are standard and have always been used in other studies including Whetten and Cameron (2015), Vitell and Davis (1990), Meyer and Herscovitch (2001), Wang and Ahmed (2004), respectively.

Since structural equation modeling (SEM) approach was used in this research. One of the prerequisites for using structural equation modeling is the fitting of measurement models. Therefore, the fitting of measurement models of the same structural validity of these questionnaires has been re-examined which is addressed in the research findings section.

Descriptive and inferential statistics were used to analyze the gathered data. The data after entry into computer was analyzed using SPSS and Amos software. In the analysis of the data, initially all variables were tested for normality, and after fulfillment of Kolmogorov-Smirnov statistical test, and confirming the normality of the variables, structural equation modeling technique was used. Structural Equation Modeling is a prolific multivariate analysis technique of the multivariate regression branch that allows researchers to test a set of regression equations simultaneously (Hooman, 2014). This method, in contrast to regression analysis for analyzing structural equations, is considered a suitable method because it allows the researcher to measure the relations between the latent and manifest variables and also provides an analysis of multi-agent relationships. In the present research, the structural modeling approach has been used to fit the measurement models, the proposed model test, and the hypotheses. 


\section{Results}

The findings showed that more than $50 \%$ of respondents were male, more than $40 \%$ of them had bachelor degree, more than $50 \%$ of them were married and more than $60 \%$ of these people were over 30 years old.

Since one of the prerequisites for modeling structural equations is the fit of measurement models; therefore, the fit of measuring models, or the validity of the questionnaire structure, was studied using the confirmatory factor analysis method and with the help of Amos software. The results are as follows:

Table 1

Fit Indexes of Measurement Models of Psychological Empowerment Measurement, Job Satisfaction, Organizational Commitment, and Organizational Innovation

\begin{tabular}{lcccccccc}
\hline Index & RMSEA & CMIN/DF & GFI & AGFI & CFI & NFI & TLI & IFI \\
\hline Global Fit & $0.08 \geq$ & $3 \geq$ & $0.9 \leq$ & $0.9 \leq$ & $0.9 \leq$ & $0.9 \leq$ & $0.9 \leq$ & $0.9 \leq$ \\
Psychological empowerment & .071 & 2.910 & .924 & .891 & .905 & .928 & .910 & .928 \\
Job satisfaction & .069 & 2.668 & .921 & .911 & .956 & .918 & .938 & .918 \\
Organizational commitment & .060 & 2.372 & .939 & .918 & .924 & .917 & .929 & .915 \\
Organizational innovation & .077 & 2.231 & .958 & .950 & .940 & .938 & .961 & .937 \\
\hline
\end{tabular}

As shown in Table 1, all fit indexes confirmed measurement models of the employees' psychological empowerment, the employees' job satisfaction, the employees' organizational commitment, and organizational innovation. As shown in Table 2, all indexes related to the four variables of the employees' psychological empowerment, the employees' job satisfaction (except for question 2), the employees' organizational commitment, and organizational innovation benefit from acceptable value of t-statistic (more than 1.98) and factor loading (more than 0.3 ), respectively. Therefore, question 2 of job satisfaction variable is eliminated from the process. 
Table 2

Standardized Factor Load and T-Value of Questions Related to Psychological Empowerment, Job Satisfaction, Organizational Commitment, and Organizational Innovation

\begin{tabular}{|c|c|c|c|c|c|c|c|c|c|}
\hline Contrast & Question & Factor loading & t-value & $\mathrm{P}$-value & Contrast & Question & Factor loading & t-value & P-value \\
\hline \multirow{3}{*}{ Competence } & Q1 & .756 & 11.650 & $<.05$ & \multirow{7}{*}{$\begin{array}{l}\text { Continuance } \\
\text { commitment }\end{array}$} & Q9 & .565 & 9.182 & $<.05$ \\
\hline & Q2 & .784 & 11.910 & $<.05$ & & Q10 & .657 & 10.296 & $<.05$ \\
\hline & Q3 & .648 & - & $<.05$ & & Q11 & .668 & 9.713 & $<.05$ \\
\hline \multirow{3}{*}{$\begin{array}{l}\text { Self- } \\
\text { determination }\end{array}$} & Q4 & .719 & 12.334 & $<.05$ & & Q12 & .663 & 10.448 & $<.05$ \\
\hline & Q5 & .657 & 11.378 & $<.05$ & & Q13 & .600 & 9.648 & $<.05$ \\
\hline & Q6 & .729 & - & $<.05$ & & Q14 & .701 & 10.916 & $<.05$ \\
\hline \multirow{3}{*}{ Impact } & Q7 & .675 & 11.101 & $<.05$ & & Q15 & .650 & 10.198 & $<.05$ \\
\hline & Q8 & .670 & 11.037 & $<.05$ & \multirow{9}{*}{$\begin{array}{l}\text { Normative } \\
\text { commitment }\end{array}$} & Q16 & .601 & - & $<.05$ \\
\hline & Q9 & .679 & - & $<.05$ & & Q17 & .667 & 9.403 & $<.05$ \\
\hline \multirow{3}{*}{ Meaning } & Q10 & .690 & 10.234 & $<.05$ & & Q18 & .615 & 8.222 & $<.05$ \\
\hline & Q11 & .712 & 10.448 & $<.05$ & & Q19 & .697 & 9.651 & $<.05$ \\
\hline & Q12 & .602 & - & $<.05$ & & Q20 & .560 & 8.402 & $<.05$ \\
\hline \multirow{3}{*}{ Trust } & Q13 & .834 & 10.132 & $<.05$ & & Q21 & .431 & 6.859 & $<.05$ \\
\hline & Q14 & .724 & 9.230 & $<.05$ & & Q22 & .654 & 9.286 & $<.05$ \\
\hline & Q15 & .641 & - & $<.05$ & & Q23 & .555 & 10.522 & $<.05$ \\
\hline \multirow{3}{*}{ Pay } & Q1 & .515 & - & - & & Q24 & .551 & - & $<.05$ \\
\hline & Q2 & .248 & 4.197 & $<.05$ & \multirow{4}{*}{$\begin{array}{c}\text { Service } \\
\text { innovation }\end{array}$} & Q1 & .621 & 10.733 & $<.05$ \\
\hline & Q3 & .343 & 5.543 & $<.05$ & & Q2 & .778 & 13.048 & $<.05$ \\
\hline \multirow{2}{*}{ Coworkers } & Q4 & .557 & - & - & & Q3 & .747 & 12.637 & $<.05$ \\
\hline & Q5 & .769 & 9.842 & $<.05$ & & Q4 & .691 & - & - \\
\hline \multirow{3}{*}{ Work } & Q6 & .689 & 10.619 & $<.05$ & \multirow{4}{*}{$\begin{array}{c}\text { Market } \\
\text { innovation }\end{array}$} & Q5 & .781 & 12.012 & $<.05$ \\
\hline & Q7 & .778 & 11.500 & $<.05$ & & Q6 & .594 & 10.536 & $<.05$ \\
\hline & Q8 & .624 & - & - & & Q7 & .615 & 10.878 & $<.05$ \\
\hline \multirow{3}{*}{ Supervision } & Q9 & .782 & 9.990 & $<.05$ & & Q8 & .752 & - & - \\
\hline & Q10 & .683 & 9.416 & $<.05$ & \multirow{4}{*}{$\begin{array}{l}\text { Process } \\
\text { innovation }\end{array}$} & Q9 & .648 & 9.107 & $<.05$ \\
\hline & Q11 & .576 & - & - & & Q10 & .538 & 7.987 & $<.05$ \\
\hline \multirow{10}{*}{$\begin{array}{l}\text { Affective } \\
\text { commitment }\end{array}$} & Q1 & .588 & 10.696 & $<.05$ & & Q11 & .638 & 10.213 & $<.05$ \\
\hline & Q2 & .684 & 44.567 & $<.05$ & & Q12 & .532 & - & - \\
\hline & Q3 & .634 & 10.828 & $<.05$ & \multirow{4}{*}{$\begin{array}{l}\text { Behavior } \\
\text { innovation }\end{array}$} & Q13 & .697 & 7.777 & $<.05$ \\
\hline & Q4 & .616 & 10.543 & $<.05$ & & Q14 & .628 & 8.120 & $<.05$ \\
\hline & Q5 & .568 & 9.816 & $<.05$ & & Q15 & .755 & 8.810 & $<.05$ \\
\hline & Q6 & .492 & 8.997 & $<.05$ & & Q16 & .510 & - & - \\
\hline & Q7 & .505 & 8.721 & $<.05$ & \multirow{4}{*}{$\begin{array}{l}\text { Strategic } \\
\text { Innovation }\end{array}$} & Q17 & .750 & 9.767 & $<.05$ \\
\hline & Q8 & .676 & - & $<.05$ & & Q18 & .814 & 10.041 & $<.05$ \\
\hline & & & & & & Q19 & .704 & 9.643 & $<.05$ \\
\hline & & & & & & Q20 & .670 & - & - \\
\hline
\end{tabular}

Factor loading $>0.3 ; \mathrm{P}$-value $<0.05 ; \mathrm{t}$-value $>1.98$

\section{Test of the Conceptual Model and Hypotheses}

In this study, structural equation modeling was used to test the conceptual model and hypotheses of the research. The results are presented in Figure 2: 


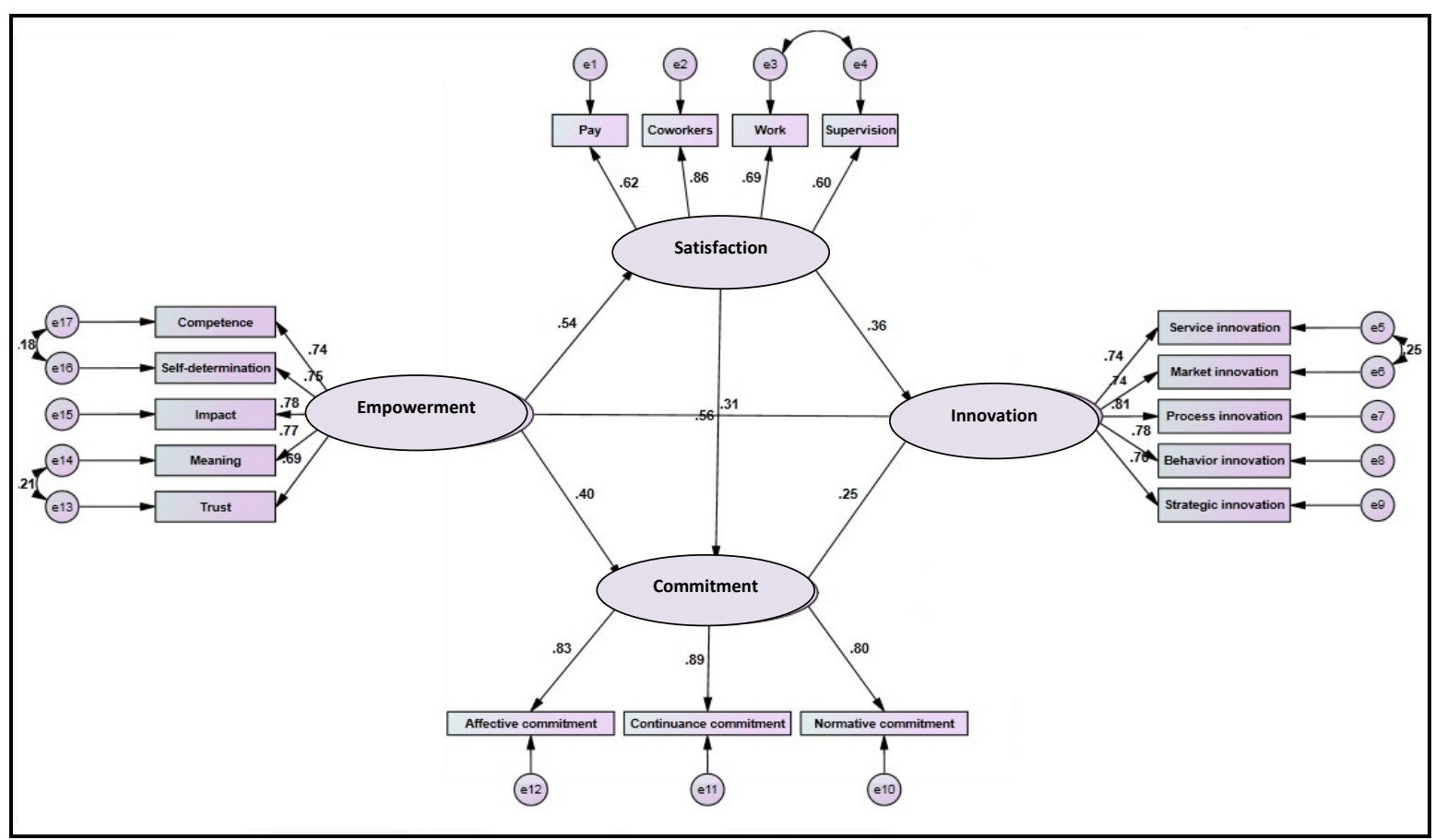

Figure 2. Model of Amos in standard estimation mode

Fit indexes in table 3 show that conceptual model of the research has a very good fit. In other words, the suggested model has appropriate fit.

Table 3

Fit Indexes of Conceptual Model

\begin{tabular}{lcccccccc}
\hline Index & RMSEA & CMIN/DF & GFI & AGFI & CFI & NFI & TLI & IFI \\
\hline Global Fit & $0.08 \geq$ & $3 \geq$ & $0.9 \leq$ & $0.9 \leq$ & $0.9 \leq$ & $0.9 \leq$ & $0.9 \leq$ & $0.9 \leq$ \\
Model & .065 & 2.953 & .921 & .891 & .926 & .953 & .941 & .953 \\
\hline
\end{tabular}

As shown in table 4, the employees' psychological empowerment had a positive effect on employees' job satisfaction, employees' organizational commitment, and organizational innovation. The employees' job satisfaction and organizational commitment had a positive effect on organizational innovation. The employees' job satisfaction had a positive effect on the employees' organizational commitment. According to these results, hypotheses 1 to 6 were confirmed.

In addition, the results of path analysis in table 5 showed that the employees' psychological empowerment beyond its direct effect on organizational innovation, indirectly influenced the organizational innovation through the employees' job satisfaction and organizational commitment, and that indirect effect was significantly higher than direct effect. Thus, mediating role of the employees' job satisfaction and organizational commitment on the relationship between the employees' psychological empowerment and organizational innovation was verified. Moreover, significant level was obtained based on the performed calculations by the Boot Strap method. The mediating role of employees' job satisfaction and organizational commitment was .001 and .001, respectively (in Boot Strap method if the level of significance is less than .05 , the role of the mediator variable is confirmed). 
Table 4

Testing of Research Hypotheses

\begin{tabular}{llcccc}
\hline Hypothesis & Path coefficient & t-value & P-value & Result \\
\hline $\mathbf{H}_{1}$ & Psychological empowerment $\rightarrow$ Organizational innovation & .308 & 4.421 & .001 & Confirmed \\
$\mathbf{H}_{2}$ & Psychological empowerment $\rightarrow$ Job satisfaction & .543 & 7.402 & .001 & Confirmed \\
$\mathbf{H}_{3}$ & Psychological empowerment $\rightarrow$ Organizational commitment & .404 & 6.932 & .001 & Confirmed \\
$\mathbf{H}_{4}$ & Job satisfaction $\rightarrow$ Organizational innovation & .360 & 4.181 & .001 & Confirmed \\
$\mathbf{H}_{5}$ & Organizational commitment $\rightarrow$ Organizational innovation & .254 & 2.587 & .010 & Confirmed \\
$\mathbf{H}_{6}$ & Job satisfaction $\rightarrow$ Organizational commitment & .556 & 8.271 & .001 & Confirmed \\
\hline
\end{tabular}

t-value $>1.96 ;$ P-value $<0.05$

Table 5

Direct, Indirect and Total Effects of Conceptual Model

\begin{tabular}{|c|c|c|c|c|}
\hline Paths & Direct effect & Indirect effect & Total effect & Kind of relation \\
\hline Psychological empowerment $\rightarrow$ Organizational innovation & .308 & .375 & .683 & Additive \\
\hline Psychological empowerment $\rightarrow$ Job satisfaction & .543 & - & .543 & Additive \\
\hline Psychological empowerment $\rightarrow$ Organizational commitment & .404 & .302 & .706 & Additive \\
\hline Job satisfaction $\rightarrow$ Organizational innovation & .360 & .141 & .502 & Additive \\
\hline Organizational commitment $\rightarrow$ Organizational innovation & .254 & - & .254 & Additive \\
\hline Job satisfaction $\rightarrow$ Organizational commitment & .556 & - & .556 & Additive \\
\hline
\end{tabular}

\section{Discussion and Conclusion}

The findings of the study indicated that the employees' psychological empowerment, beyond its direct influence, exerts indirect effect on organizational innovation through the mediations of the employees' job satisfaction and organizational commitment in which the extent of indirect effect is significantly higher than that of direct one. The findings of the study were also analyzed and compared with the results of the different studies.

The findings revealed that the employees' psychological empowerment has a positive and significant effect on organizational innovation in Regional Power Company of Kerman. This finding is coordinated with the results of the research of Yang and Alison (2011), Ertürk (2012), Singh and Sarkar (2012), Berraies, Chaher and Benyahia (2014), Celik, Iraz, Cakıci and Celik (2014), and Madhavan (2014).

Yang and Alison (2011) concluded that there is a positive relationship between the level of employee involvement and the organizational innovation. Ertürk (2012) concluded psychological empowerment of the employees is strongly and positively related to innovation capability. Singh and Sarkar (2012) found that psychological empowerment has positive impact on innovative behaviors. Berraies, Chaher and Benyahia (2014) expressed that employees' empowerment has a positive effect on innovation. Celik, Iraz, Cakıci and Celik (2014) suggested that there is a meaningful relationship between employees' empowerment and innovativeness. Madhavan (2014) noted that there is positive and significant relationship between employees' empowerment and their innovation in the work.

The results also showed that the employees' psychological empowerment has a positive and significant effect on the employees' job satisfaction in Regional Power Company of Kerman. This finding is consistent with the results of the research of Laschinger, Finegan, Shamian and Wilk (2004), Hamed (2010), Mushipe (2011), Kazlauskaite, Buciuniene and Turauskas (2012), and Elnaga and Imran (2014). 
Laschinger et al. (2004) concluded that workplace empowerment has an impact on job satisfaction. Hamed (2010) found that there is a positive association between empowerment and job satisfaction. Mushipe (2011) found that there is a positive relationship between employee involvement and job satisfaction. Kazlauskaite, Buciuniene and Turauskas (2012) stated that organizational empowerment has an impact on job satisfaction. Elnaga and Imran (2014) concluded that empowerment can lead to job satisfaction.

Another finding of the study indicated that the employees' psychological empowerment has a positive and significant effect on the employees' organizational commitment in Regional Power Company of Kerman. This finding is consistent with the results of the research of Liu, Fellows and Chiu (2006), Chen and Chen (2008), Ismail, Mohamed, Sulaiman, Mohamad and Yusuf (2011), Kazlauskaite, Buciuniene and Turauskas (2012), and Goudarzvandchegini and Kheradmand (2013).

Liu, Fellows and Chiu (2006) concluded that perceived empowerment correlates with organizational commitment. Chen and Chen (2008) found that there is a positive and significant relationship between dimensions of empowerment and organizational commitment. Ismail, et al. (2011) claimed that there is a positive relationship between empowerment and organizational commitment. Kazlauskaite, et al. (2012) concluded that organizational empowerment has an impact on affective commitment. Goudarzvandchegini and Kheradmand (2013) stated that there is significant relationship between empowerment and organizational commitment.

Another finding of the study revealed that employee's job satisfaction has a positive and significant effect on organizational innovation in Regional Power Company of Kerman. This finding is coordinated with the results of the research of Shipton, West, Parkes, Dawson and Patterson (2006), Lambert and Hogan (2010), Tien and Chao (2012), and Ghoochkanloo and Talebieshlaghi (2016).

Shipton, et al. (2006) concluded that there is a relationship between aggregate job satisfaction and innovation. Lambert and Hogan (2010) posited that perceptions of organizational innovation have statistically significant positive associations with job satisfaction. Tien and Chao (2012) noted that job satisfaction has an impact on organizational innovation. Ghoochkanloo and Talebieshlaghi (2016) found that employee's job satisfaction has a significant impact on the innovation of the organization.

Another finding of the study showed that the employees' organizational commitment has a positive and significant effect on organizational innovation in Regional Power Company of Kerman. This finding is consistent with the results of the research of Ming and Ying (2010), Lambert and Hogan (2010), Holliman (2012), and Rostami, Veismoradi and Akbari (2012).

Ming and Ying (2010) concluded that affective commitment and continuance commitment have an effect on both technological innovation and administrative innovation and also normative commitment has effect on technological innovation. Lambert and Hogan (2010) found that organizational perceptions have statistically significant positive associations with organizational commitment. Holliman (2012) claimed that there is a relationship between organizational commitment and innovation and higher levels of commitment are associated with higher levels of innovation. Rostami, et al. (2012) noted that there is a significant relationship between organizational commitment and innovation. 
Another finding of the study indicated that the employees' job satisfaction has a positive and significant effect on employee's organizational commitment in Regional Power Company of Kerman. This finding is coordinated with the results of the research of Meyer, Stanley, Herscovitch and Topolnytsky (2002), Adekola (2012), Yucel and Bektas (2012), and Suma and Lesha (2013).

Meyer, et al. (2002) concluded that job satisfaction is a determinative of organizational commitment. Adekola (2012) found that organizational commitment has a significant impact on job satisfaction. Yucel and Bektas (2012) stated that job satisfaction positively correlated with organizational commitment. Suma and Lesha (2013) noted that dimensions of job satisfaction as work-itself, quality of supervision and pay have significant positive influence on organizational commitment of employees.

\section{References}

Abdulla, J., Djebarni, R., \& Mellahi, K. (2011). Determinants of job satisfaction in the UAE: A case study of the Dubai police. Personnel Review, 40(1), 126-146.

Adekola, B. (2012). The impact of organizational commitment on job satisfaction: A study of employees at Nigerian universities. International Journal of Human Resource Studies, 2(2), 1-17.

Allen, N. J., \& Meyer, J. P. (1990). The measurement and antecedents of affective, continuance and normative commitment to the organization. Journal of occupational and organizational psychology, 63(1), 1-18.

Alshekaili, S. A. R., \& Boerhannoeddin, A. (2011). Human capital approach towards enhancing innovation performance in Omani industrial firms: The role of knowledge management. Progress in Business Innovation and Technology Management, 1(1), 23-33.

Antoncic, J. A., \& Antoncic, B. (2011). Employee satisfaction, entrepreneurship and firm growth: A model. Industrial Management and Data Systems, 111(4), 589-607.

Bas, C. L., Mothe, C., \& Nguyen-Thi, T. U. (2015). The differentiated impacts of organizational innovation practices on technological innovation persistence. European Journal of Innovation Management, 18(1), 110-127.

Berraies, S., Chaher, M., \& Benyahia, K. (2014). Employee empowerment and its importance for trust, innovation and organizational performance. Business Management and Strategy, 5(2), 82-103.

Bogler, R., \& Somech, A. (2004). Influence of teacher empowerment on teacher organizational commitment, professional commitment and organizational citizenship behavior in schools. Teaching and Teacher Education, 20(3), 277-289.

Brief, A. P., \& Weiss, H. M. (2002). Organizational behavior: Affect in the workplace. Annual Review of Psychology, 53(1), 279-307.

Celik, A., Iraz, R., Cakıci, A. B., \& Celik, N. (2014). The effects of employee empowerment applications on organizational creativity and innovativeness in enterpriseses: The case of Oiz. European Scientific Journal, 10(10), 99-107.

Chen, H. F., \& Chen, Y. C. (2008). The impact of work redesign and psychological empowerment on organizational commitment in a changing environment: An example from Taiwan state-owned enterprises. International Public Management Association for Human Resources, 37(3), 279-302.

Cichy, R. F., Cha. J., \& Kim S. (2009). The relationship between organizational commitment and contextual performance among private club leaders. International Journal of Hospitalist Management, 28(1), 53-62.

Dee, J. R., Henkin, A. B., \& Singleton, C. A. (2006). Organizational commitment of teachers in urban schools: Examining the effects of team structures. Urban Education, 41(6), 603-627.

Elnaga, A. A., \& Imran, A. (2014). The impact of employee empowerment on job satisfaction theoretical study. American Journal of Research Communication, 2(1), 13-26.

Ertürk, A. (2012). Linking psychological empowerment to innovation capability: investigating the moderating effect of supervisory trust. International Journal of Business and Social Science, 3(14), 153-165.

Ghoochkanloo, S., \& Talebieshlaghi, M. (2016). The impact of job satisfaction on organizational innovation (Digikala company case study). The International Journal of Business and Management, 4(6), 54-58.

Goudarzvandchegini, M., \& Kheradmand, R. (2013). The relationship between empowerment and organizational commitment. International Research Journal of Applied and Basic Sciences, 4(5), 1047-1056. 
Gumusluoglu, L., \& Ilsev, A. (2009). Transformational leadership, creativity and organizational innovation. Journal of Business Research, 62(4), 461-473.

Gunlu, E., Aksarayli, M., \& Sahin Perçin, N. (2010). Job satisfaction and organizational commitment of hotel managers in Turkey. International Journal of Contemporary Hospitality Management, 22(5), 693-717.

Hamed, S. S. (2010). Antecedents and consequences of employees empowerment. Management Review: An International Journal, 5(1), 64-94.

Herbert. I. (2009). Business transformation through empowerment and the implication for management control system. Journal of Human Resource Costing and Accounting, 13(3), 221-244.

Hill, C. W. L., \& Jones, G. R. (2012). Strategic management: An integrated approach (10 ${ }^{\text {th }}$ Edition). Boston: Houghton Mifflin Company.

Holliman, S. L. (2012). Exploring the effects of empowerment, innovation, professionalism, conflict, and participation on teacher organizational commitment (Unpublished doctoral dissertation). University of Iowa, Iowa, USA.

Hooman, H. A. (2014). Structural equation modeling by using LISREL (6 $6^{\text {th }}$ Edition). Tehran: Samt Press.

Ismail, A., Mohamed, H. A. B., Sulaiman, A. Z., Mohamad, M. H., \& Yusuf, M. H. (2011). An empirical study of the relationship between transformational leadership, empowerment and organizational commitment. Business and Economics Research Journal, 2(1), 89-107.

Jafari, V., Moradi, M. A., \& Ahanchi, M. (2013). An examination of the relationship between empowerment and organizational commitment (case study Kurdistan province electric staff). Interdisciplinary Journal of Contemporary Research in Business, 4(12), 860-868.

Kazlauskaite, R., Buciuniene, I., \& Turauskas, L. (2012). Organizational and psychological empowerment in the HRMperformance linkage. Employee Relations, 34(2), 138-158.

Lambert, E. G., \& Hogan, N. L. (2010). Wanting change: The relationship of perceptions of organizational innovation with correctional staff job stress, job satisfaction and organizational commitment. Criminal Justice Policy Review, 21(2), 160184.

Landry, R., Amara, N., \& Lamari, M. (2002). Does social capital determine innovation? To what extent?. Technological Forecasting and Social Change, 69(7), 681-701.

Laschinger, H. K. S., Finegan, J. E., Shamian, J., \& Wilk, P. (2004). A longitudinal analysis of the impact of workplace empowerment on work satisfaction. Journal of Organizational Behavior, 25(4), 527-545.

Lau, W. K. J. (2010). Empowerment of non-academic personnel in higher education: exploring associations with perceived organizational support for innovation and organizational trust. (Unpublished doctoral dissertation).University of Iowa, Iowa, USA.

Liu, A. M. M., Fellows, R., \& Chiu, W. M. (2006). Work empowerment as an antecedent to organizational commitment in the Hong Kong quantity surveying profession. Surveying and Built Environment, 17(2), 63-72.

Lund, D. B. (2003). Organizational culture and job satisfaction. Journal of Business and Industrial Marketing, 18(3), $219-236$.

Madhavan, N. (2014). Employees empowerment towards innovation. Reviews of Literature, 2(2), 1-6.

Meyer, J. P., \& Herscovitch, L. (2001). Commitment in the workplace: Toword a general model. Human Resuorce Management Review, 11(3), 299-326.

Meyer, J. P., Stanley, D. J., Herscovitch, L., \& Topolnytsky, L. (2002). Affective, continuance, and normative commitment to the organization: A meta-analysis of antecedents, correlates, and consequences. Journal of Vocational Behavior, 61(1), 2052 .

Ming, L., \& Ying, Z. Z. (2010). How does organizational commitment affect organizational innovation? Proceedings of the International Conference on E-Business and E-Government, 1164-1170.

Mol, M. J., \& Birkinshaw J. (2009). The sources of management innovation: When firms introduce new management practices. Journal of Business Research, 62(12), 1269-1280.

Mushipe, Z. J. (2011). Employee empowerment and Job satisfaction: A study of the employees in the food manufacturing sector in Zimbabwe. Interdisciplinary Journal of Contemporary Research in Business, 3(8), 18-41.

Petter, J., Byrnes, P., Choi, D. L., Fegan, F., \& Miller, R. (2002). Dimensions and patterns in employee empowerment: Assessing what matters to street level bureaucrats. Journal of Public Administration Research and Theory, 12(3), 377-400.

Pizarro, I., Real, J. C., \& Rosa, M. D. (2009). The role of entrepreneurial culture and human capital in innovation. Working Paper, Department of Business Administration, Universidad Pablo de Olavide, Sevilla, Spain.

Quinn, J. B. (2000). Outsourcing innovation: The new engine of growth. Sloan Management Review, 41(4), 13-28. 
Racela, O. C. (2014). Customer orientation, innovation competencies, and firm performance: A proposed conceptual model. Procedia - Social and Behavioral Sciences, 148, 16-23.

Rahimnia, F., \& Sajjad, A. (2015). The impact of strategic orientations on the performance of Khorasan science and technology Parks companies with mediating role of organizational innovation. Innovation Management Journal, 4(2), 87114.

Rehman, K., Rehman, Z. U., Saif, N., Khan, A. S., Nawaz, A., \& Rehman, U. S. (2013). Impacts of job satisfaction on organizational commitment: A theoretical model for academicians in HEI of developing countries like Pakistan. International Journal of Academic Research in Accounting, Finance and Management Sciences, 3(1), 80-89.

Rostami, R., Veismoradi, A., \& Akbari, P. (2012). The study relationship between organizational climate, organizational commitment and innovation in cement industry of Iran (case study: cement west co. of Kermanshah). Technical Journal of Engineering and Applied Sciences, 2, 497-505.

Shipton, H. J., West, M. A., Parkes, C. L., Dawson, J. F., \& Patterson, M. G. (2006). When promoting positive feelings pays: Aggregate job satisfaction, work environment features and innovation in manufacturing organizations. European Journal of Work and Organizational Psychology, 15(4), 404-430.

Singh, M., \& Sarkar, A. (2012). The relationship between psychological empowerment and innovative behavior: A dimensional analysis with job involvement as mediator. Journal of Personnel Psychology, 11(3), 127-137.

Steiber, A. (2012). Organizational innovations: A conceptualization of how they are created, diffused, and sustained. (Unpublished doctoral dissertation). Department of Technology Management and Economics, Chalmers University of Technology, Gothenburg, Sweden.

Suma, S., \& Lesha, J. (2013). Job satisfaction and organizational commitment: The case of shkodra municipality. European Scientific Journal, 9(17), 41-51.

Thomas, K. W., \& Velthouse, B. A. (1990). Cognitive elements of empowerment: An interpretive model of intrinsic task motivation. Academy of Management Journal, 15(4), 666-681.

Tamayo-Torres, I., Ruiz-Moreno, A., \& Verdú, A. J. (2010). The moderating effect of innovative capacity on the relationship between real options and strategic flexibility. Industrial Marketing Management, 39(7), 1120-1127.

Tien, L. C., \& Chao, H. S. (2012). Effects of information culture and job satisfaction on the organizational innovation - a study of different leadership styles as a moderatoritle. Advances in Management and Applied Economics, 2(3), 83-110.

Vitell, S. J., \& Davis, D. L. (1990). The relationship between ethics and job satisfaction: An empirical investigation. Journal of business ethics, 9(6), 489-494.

Wang, C. L., \& Ahmed, P. K. (2004). The development and validation of the organizational innovativeness construct using confirmatory factor analysis. European Journal of Innovation Management, 7(4), 303-313.

Whetten, D. A., \& Cameron, K. S. (2015). Developing management skills ( $9^{\text {th }}$ Edition). New York: Pearson.

Yang, Y., \& Alison, M. K. (2011). Diversity and organizational innovation: The role of employee involvement. Journal of Organizational Behavior, 32(8), 1062-1083.

Yesil, S., Koska, A., \& Buyukbese, T. (2013). Knowledge sharing process, innovation capability and innovation performance: An empirical study. Procedia - Social and Behavioral Sciences, 75, 217-225.

Yucel, I., \& Bektas, C. (2012). Job satisfaction, organizational commitment and demographic characteristics among teachers in Turkey: Younger is better?. Procedia - Social and Behavioral Sciences, 46, 1598-1608. 